\title{
Removal of lead from polluted Musi Water using Biosurfactants (Rhamnolipids)
}

\section{K. Nagajyothi}

\begin{abstract}
The largest city discharges about 600 million litres of waste water into the River Musi. Due to indiscriminate urbanisation and lack of planning, Musi has been the receptacle for the domestic and industrial waste water in the city. High levels of chemical, biomedical, biological, pharmaceutical and industrial contamination cause ground water pollution has endangered aquatic life(1). People depend on the vegetables and fruits grown on Musi river bed leading to diseases and even miscarriages. The polluted water contains high levels of lead which leads to damage of nervous system, hematopoietic system, renal system, cardiovascular system, reproductive system etc.(2) Key word: Musi water,musi river etc.,
\end{abstract}

\section{INTRODUCTION:}

Although chemosynthetic surfactants could help ion desorption of heavy metals from polluted water, they cause serious impact on water environment and human health due to high toxicity and non-biodegradable. Bio surfactants have low toxicity and can be easily synthesised from renewable resources(3). Rhamnolipids are surfactants produced by microorganism from renewable energy resources are capable of removing heavy metals by complexion at optimum conditions

\section{EXPERIMENT}

Musi water samples and Palak samples were collected from Peerzadiguda Area. The samples were tested for the quantity of lead in the presence and absence of biosurfactants. The bio surfactants are prepared by culturing bacteria in agar media, $\mathrm{NaCl}(5 \mathrm{~g} / \mathrm{lit})$ and Rice Bran Oil (10\% v/v). Incubation was carried out at room temperature in a rotary shaking machine at $150 \mathrm{rpm}$ for 4 days. The cultured pseudomonas aerugenosa was centrifuged and treated with hexane and chloroform followed by evaporation and drying. Fresh leafy palak leaves were collected from the farm grown on Muzi river bed at

Peerzadiguda. The leaves were crushed and oxidised in the presence of air and then fired. Inert graphite rod was used to test the concentration of lead in water and leaf samples. Atomic absorption spectrophotometer (AA-2759 Shimadzu) was used to find the metal concentration and FT-IR was used to study the absorption of metals by the bio surfactant.

\section{RESULTS AND DISCUSSIONS}

The surfactant solutions of different concentrations were prepared and treated with the musi water and palak samples. The $\mathrm{pH}$ was maintained at 6 and contact time was ten minutes.

Revised Manuscript Received on September 22, 2019.

Dr. K. Nagajyothi, Swami Vivekananda Institute of Technology,

Secunderabad

\begin{tabular}{|c|c|c|}
\hline $\begin{array}{c}\text { Concn of } \\
\text { P. Aeruginosa } \\
(\mathrm{ppm})\end{array}$ & $\begin{array}{c}\text { Concn of Pb in } \\
\text { Musi water(ppm) }\end{array}$ & $\begin{array}{c}\text { Concn of Pb in } \\
\text { Palak leaves } \\
(\mathrm{ppm})\end{array}$ \\
\hline 0 & 0.324 & 0.141 \\
\hline 2 & 0.302 & 0.122 \\
\hline 4 & 0.263 & 0.103 \\
\hline 6 & 0.221 & 0.092 \\
\hline 8 & 0.172 & 0.080 \\
\hline 10 & 0.098 & 0.041 \\
\hline 12 & 0.094 & 0.037 \\
\hline 14 & 0.091 & 0.033 \\
\hline 16 & 0.092 & 0.034 \\
\hline 18 & 0.090 & 0.029 \\
\hline 20 & 0.090 & 0.028 \\
\hline
\end{tabular}

The effect of contact time has been studied at surfactant concentration $10 \mathrm{ppm}$.

\begin{tabular}{|l|l|l|l|l|l|l|l|l|l|l|l|}
\hline $\begin{array}{l}\text { Contact } \\
\text { time in }\end{array}$ & 0 & 2 & 4 & 6 & 8 & 1 & 1 & 1 & 1 & 1 & 2 \\
Min & & & & & & 0 & 2 & 4 & 6 & 8 & 0 \\
\hline $\begin{array}{l}\text { Concn } \\
\text { of Pb }\end{array}$ & 3 & 3 & 3 & 2 & 1 & 0 & 0 & 0 & 0 & 0 & 0 \\
in Musi & 2 & 2 & 0 & 2 & 6 & 9 & 9 & 9 & 9 & 9 & 9 \\
Water( & 4 & 2 & 4 & 3 & 1 & 5 & 6 & 5 & 4 & 3 & 3 \\
ppm) & & & & & & & & & & & \\
\hline
\end{tabular}

The optimum concentration of the surfactant was found to be $10 \mathrm{ppm}$ and effective contact time was 10 minutes. 

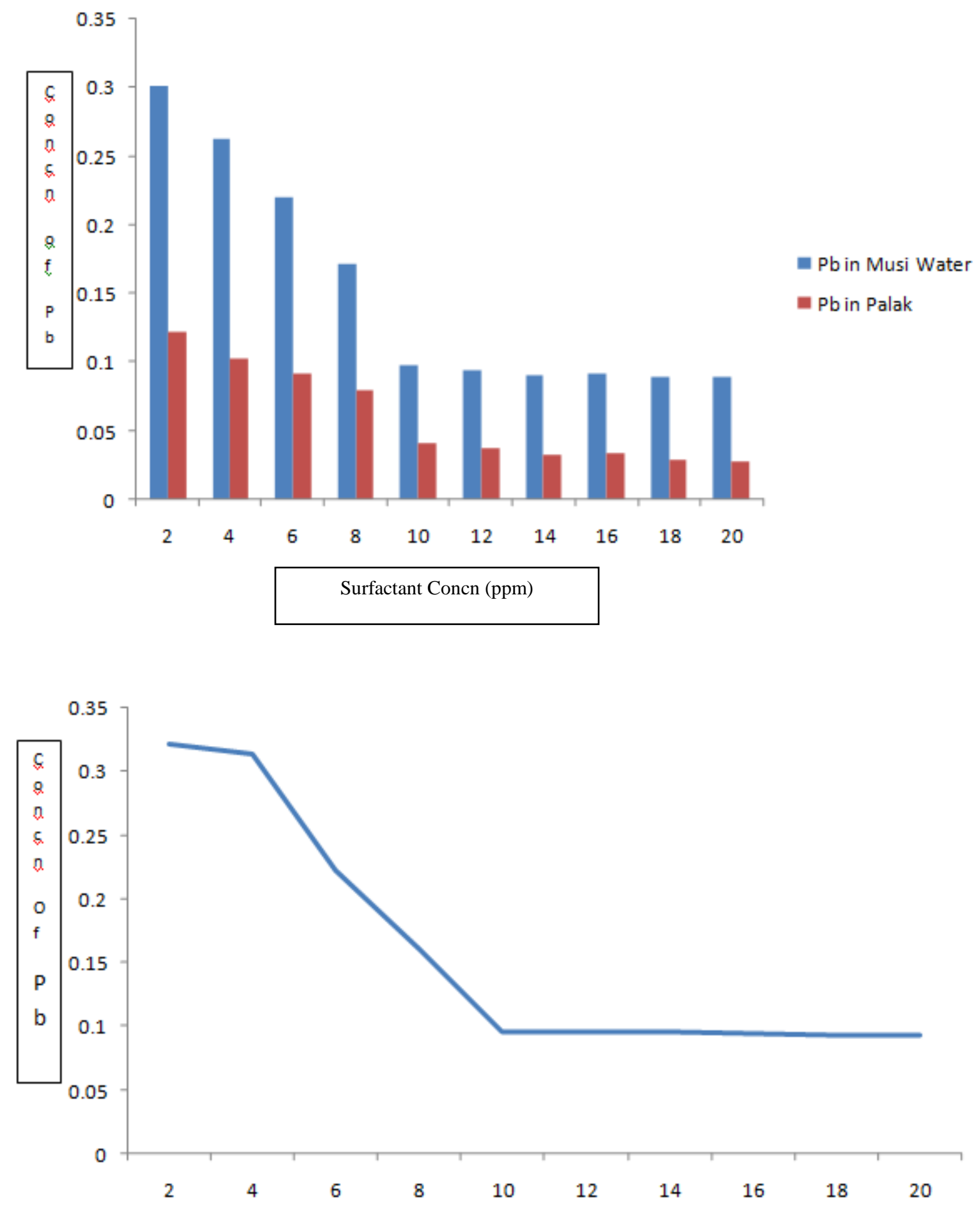

Contact time (min) 
FT-IR spectra indicate a strong peak at $3417 \mathrm{~cm}-1$ and at $1643 \mathrm{~cm}-1$ indicate asymmetric stretching vibration of $\mathrm{C}=\mathrm{O}$. The C-H stretching vibration was indicated at $2854 \mathrm{~cm}-1$. The weak band between $1370-1470 \mathrm{~cm}-1$ indicate bending vibration of the $-\mathrm{CH}_{3}$ and $-\mathrm{CH}_{2}$ chains. $1110 \mathrm{~cm}-1$ peak indicated the $\mathrm{C}-\mathrm{O}$ stretching vibration. The presence of $-\mathrm{OH}$ and $\mathrm{COOH}$ in the surfactant act as binding sites in removing toxic pollutants.

The absorption capacity was calculated using the formula

$\mathrm{C}_{\mathrm{A}}=\underline{\left(\mathrm{C}_{\mathrm{f}}-\mathrm{C}_{\mathrm{i}}\right) \times \mathrm{v}}$

Where CA is the Absorption Capacity of the surfactant, $C_{f}$ is the final concentration of metal ions after treating with surfactant, $\mathrm{C}_{\mathrm{i}}$ is the initial concentration of surfactant.

The average absorption coefficient was found to be 110 $\mathrm{mg} / \mathrm{lit}$.

\section{CONCLUSIONS}

Lead was absorbed effectively from water and palak by the biosurfactant prepared by the fermentation of Rice bran oil through the formation of pseudomonas Aeriginous. The sorption capacity was found to be $110 \mathrm{mg} / \mathrm{lit}$.

\section{REFERENCES}

1. .Heavy metal in aquatic ecosystem emphasising its effect on tissue bioaccumulation and histopathology, Mahino Fathima, Journal of Environment Science and Technology, Vol.7, 1-15, 2014

2. Assi MA, Hezmee MNM, Haron AW, Sabri MY, Rajion MA. The detrimental effects of lead on human and animal health. Veterinary World, Vol 9, 660-671, 2016

3. Absorption of heavy metals from leafy vegetables grown using Musi water, K. Nagajyothi, Journal of Environmental Science, Toxicology and Food Technology, Vol11, 30-31, 2017 